\title{
耐越流侵食性向上のための河川堤防 補強技術の提案 \\ REINFORCING TECHNOLOGY OF RIVER LEVEE FOR INCREASING RESISTANCE AGAINST OVERFLOW EROSION
}

\author{
倉上由貴 ${ }^{1}$-二瓶泰雄 ${ }^{2}$ 矢田孝次朗 ${ }^{3} \cdot$ 山㠃達也 $^{3} \cdot$ 山口晋平 ${ }^{4}$ \\ - 川邊翔平 ${ }^{5}$ - 菊池喜昭 ${ }^{6} \cdot$ 龍岡文夫 $^{7}$
}

Yuki KURAKAMI, Yasuo NIHEI, Kojiro YADA, Tatsuya YAMAZAKI, Shinpei YAMAGUCHI, Shohei KAWABE, Yoshiaki KIKUCHI and Fumio TATSUOKA

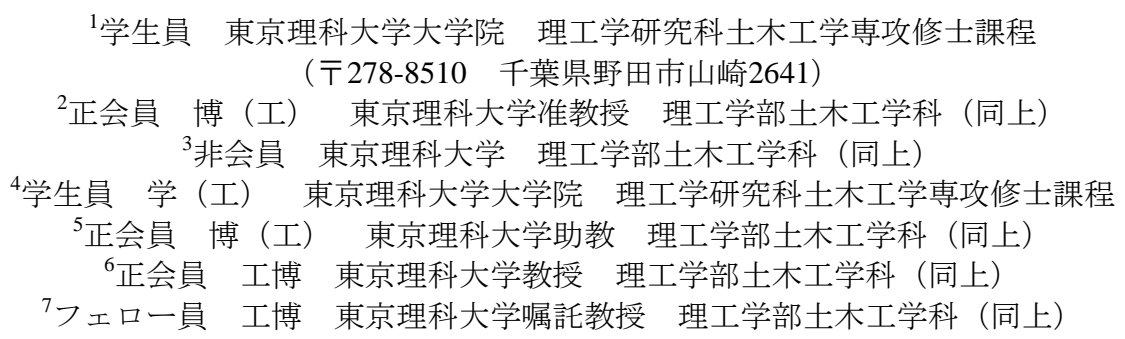

Levee breaches occurred at a great number of places in Japan mainly due to overflow of huge flood. To increase the resistance of levee to overflow erosion, we propose a new type of levee in which concrete panels connected to geogrid layers reinforcing the sand cover the slopes and crest of the levee. Various laboratory tests were conducted to evaluate the resistance of this method to overflow erosion. The results indicated that 1) the sand backfill having a degree of compaction lower than about $85 \%$ has low resistance to overflow erosion due to too large infiltration; and 2) the proposed type of levee can survive overflow continuing for a long duration showing that it can function effectively as a flood barrier.

Key Words: levee, geotextile, overflow, erosion, flood

\section{1. 序論}

2011 年新潟・福島豪雨や紀伊半島における台風 1112 号 災害のように，局所的な異常降雨に伴う超過洪水の発生 とそれによる堤防の越流決壊が各地で頻発している ${ }^{1), 2) . ~}$ 河川堤防は「計画高水位以下の水位に対して流水の通常 の作用に対して安全な構造物」とし，この作用として耐 浸透性，而侵食性（堤外地），耐震性を考慮して設計さ れている ${ }^{3)}$ 。そのため, 計画高水位を上回り，長時間越 水するような超過洪水に耐えることを前提として堤防設 計はなされていない. 今後予想される豪雨・台風災害の 激化に備えた防災・減災先進社会を実現するためには， 「想定外」の超過洪水対策の重要性が指摘されており ${ }^{1)}$, そのためには. 堤防の越流侵食対策を本格的に進めてい くことは必要不可欠である.

上述したように，一般的な河川堤防では超過洪水に対 応していないが，既存の耐越水用の堤防としては，高規
格堤防(スーパー堤防) とアーマ・レビーが挙げられる ${ }^{4)}$. しかしながら, 後述するように, これらはコスト面もし くは耐越流侵食性の面で問題がある。 そのため, 既存技 術とは異なる新しい堤防強化技術の開発が急務である.

本研究では，而越流侵食性を大幅に向上させて，粘り 強く壊れない河川堤防補強技術を開発する。ここでは, 越流侵食に対する堤防強化技術として，最新の盛土工法 であるジオシンセティックス補強土（GRS，GeosyntheticReinforced Soil）と堤防のり面のコンクリート製被覆工を一 体化した「GRS 河川堤防」を提案する. GRS工法自体は, 而震性が極めて優れた盛土・橋梁補強技術として既に実 用化されている ${ }^{5)}$ ） . また, GRS工法は越流侵食対策と して津波防潮堤の補強技術に応用され，一定の効果が確 認されている ${ }^{8)}$,9). 本論文では，一般的な 2 割勾配の堤 防を基準として，新形式（GRS 堤防）や従来形式（アー マ・レビー）を含むいくつかの補強条件や締固め度を変化 させて堤防越流実験を実施する. それらの結果に基づい 


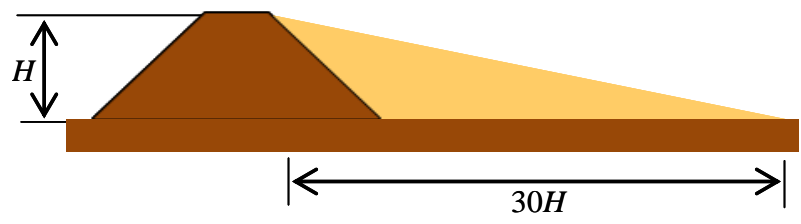

(a) 高規格堤防

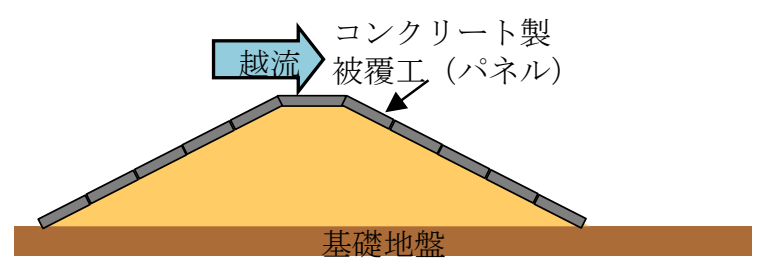

(b) アーマ・レビー

図-1 従来形式河川堤防の模式図

て，堤防の侵食状況亡補強条件の関係性を明らかにする と共に，GRS 河川堤防の有効性を検証する.

\section{GRS河川堤防の概要}

\section{（1）従来形式の堤防について}

前述したように，而越水機能を強化した堤防として， 高規格堤防とアーマ・レビーが存在する ${ }^{3), 4)}$. このうち, 高規格堤防は，図-1（a）に示寸ように，通常の堤防より もはるかに幅広で, 非常に緩い裏のり勾配を有しており, 越流時の耐侵食性・耐浸透性を向上させている。しかし ながら，高規格堤防の施工を行うには，堤内地の広範な 土地が必要であるため, 建設コストが非常に高く, 土地 利用の制約も強く社会的影響が甚大であり，実際の高規 格堤防の施工は長期化が予想される.

一方，耐越水堤防とも呼ばれるアーマ・レビーは（図 -1（b）），通常の堤防形状を変えず，堤防の天端や裏の り面，のり尻において種々の被覆工（保護工）を設置す るものである.このように，原則的に土堤である堤体表 面を保護工でカバーすることで，越流や浸透に対する強 度を向上させている. しかしながら, 越流量が大きい場 合には, これらの保護工も掃流されてしまう恐れが高く, 実際，東日本大震災では，多くのコンクリート製被覆工 でカバーされた防潮堤や河川堤防が壊れて多くは完全に 消失している ${ }^{8)}$. そのため, 単に堤体表面に被覆工を置 くのではなく, 越流侵食に対して有効に強化するための 更なる工夫が大きな課題である．また，土堤そのものの 而侵食性の検討がなされているものの ${ }^{10)}$, 締固め度など の物理特性との関連性は不明な点が多い.

\section{（2）新形式堤防について}

堤防の而越流侵食性を強化するために，図-2 に示すよ うに，堤防表・裏のり面及び天端の 3 面にわたりコンク

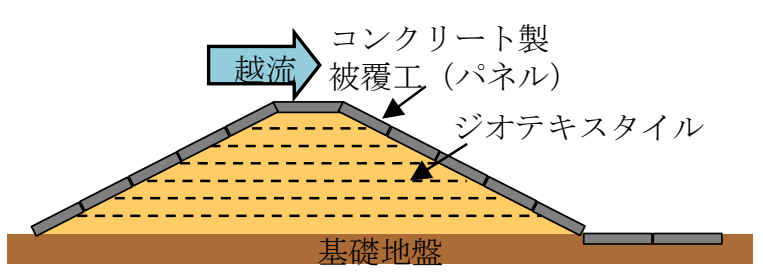

（a）全体補強

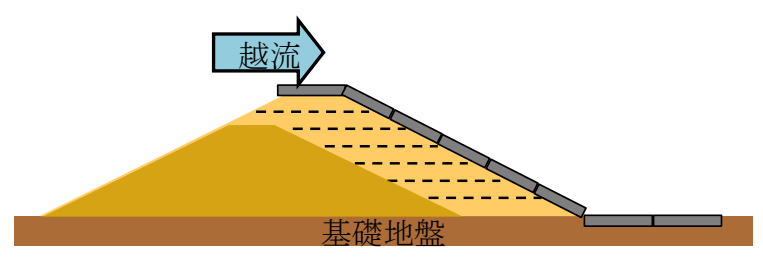

(b) 部分補強

図-2 新形式河川堤防の概念図

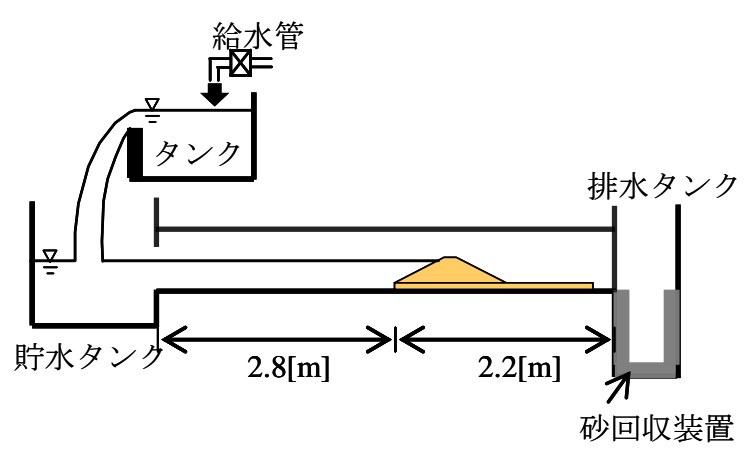

図-3 水平開水路の概略図

リート製被覆工（保護工もしくはのり面工）を設置し， かつ，堤体内にジオテキスタイル等の面状補強材を敷設 し，それらを結合した GRS 河川堤防を提案する. 一般的 な堤防補強時には，既存堤防の上に盛土し高上げや裹腹 付けなどをすることから，新形式堤防では，GRS 補強材 による堤体の補強を堤体全体にわたり行うケース（全体 補強）と上部と裏のり面のみを補強するケース（部分補 強）を想定している. また，ジオテキスタイルを敷設す るため, 盛土の締固めが容易になる. 以上のことから, 新形式堤防では耐侵食性が著しく向上することが期待さ れる. さらに, 新形式堤防では堤体表面をコンクリート 製被覆工でカバーするため降雨や河川水の浸透対策にも 有効である.このように，新形式堤防は，堤体断面積を 増やさずに，耐侵食性・耐浸透性を大幅に強化すること が可能な技術として期待している.

\section{3. 室内実験の概要}

上述した新形式堤防の而越流侵食性を検証寸るために, 図-3 に示寸長さ $5.0 \mathrm{~m}$, 幅 $0.2 \mathrm{~m}$, 高さ $35 \mathrm{~cm}$ の水平開水路 に各種の模型堤防を設置し，堤防越流実験を行う。堤防 模型の形状としては，図-4 に示すように，高さを $20 \mathrm{~cm}$, 天端幅を $10 \mathrm{~cm}$ とし, 表・裹のり面は一般的な 2 割勾配と 


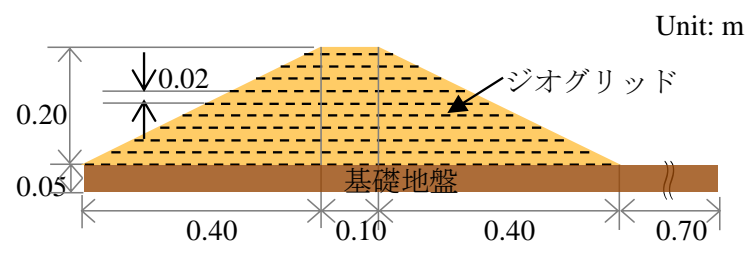

図-4 模型堤防の断面形

表-1 実験条件

\begin{tabular}{|c|c|c|c|}
\hline \multirow{2}{*}{ No. } & \multirow{2}{*}{$\operatorname{Dc}(\%)$} & \multicolumn{2}{|c|}{ 対策 } \\
\hline & & 補強材 & パネル \\
\hline 1 & 75 & \multirow{4}{*}{\multicolumn{2}{|c|}{ 無 }} \\
\hline 2 & 85 & & \\
\hline 3 & 90 & & \\
\hline 4 & 95 & & \\
\hline 5 & \multirow{3}{*}{85} & 有 & 無 \\
\hline 6 & & 無 & 有 \\
\hline 7 & & 有 & 有 \\
\hline
\end{tabular}

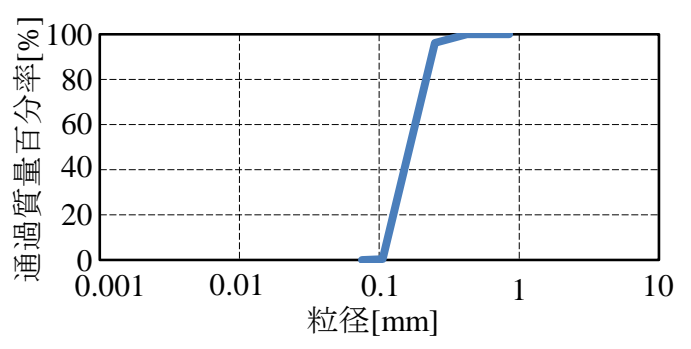

図-5 豊浦砂の粒度分布

している.ここでは, 模型縮尺を $1 / 25$ を目安としており, 実スケールでは高さ $5 \mathrm{~m}$ の堤防を想定している. 実験では, 基礎地盤（厚さ $5 \mathrm{~cm}$ ）の上に堤防模型を置き，堤防の越 流侵食過程で重要となる裏のり尻における洗掘 ${ }^{4}$ をを考慮 した実験としている.この堤体高さや基礎地盤厚さは, 実験水路で設定できる範囲で最大規模のものを選定して いる. 後述する実験結果から基本的な破堤現象が再現さ れており, これらの条件でも問題ないものと考えられる.

堤防条件としては，表-1に示すように，まず，土堤の 而越流侵食性に対する締固め度 $D_{c}$ の影響を定量的に見 るために，無補強で，JIS A 1210 に基づく標準プロクター 締固めエネルギーに対する締固め度 $D_{c}$ を $75,85,90,95 \%$ の 4 ケース設定する. 次に, 締固め度 $D_{c}$ は $85 \%$ と一定と し, 補強条件を面状補強材 (ジオグリッド) のみ (Case5), 堤防の表のり面・天端・裏のり面に被覆工（パネル）の みを敷設したもの（従来形式，Case6），ジオグリッドと 被覆工を結合した新形式（Case7）とした全 3 ケースとす る. ここで, ジオグリッドとはジオテキスタイルの一種 であり，ポリエチレン製の補強拘束ネット（引張強度 $16 \mathrm{kN} / \mathrm{m}$ ，前田工繊侏製）を使用している。 また，パネル として, 元々の堤防サイズを考慮して, コンクリートと 比重がほぼ同じで, 厚さ $0.5 \mathrm{~cm}$ のアルミニウム板を使用し た. 堤体材料としては, 最適含水比 $16 \%$ の湿潤豊浦砂 (図
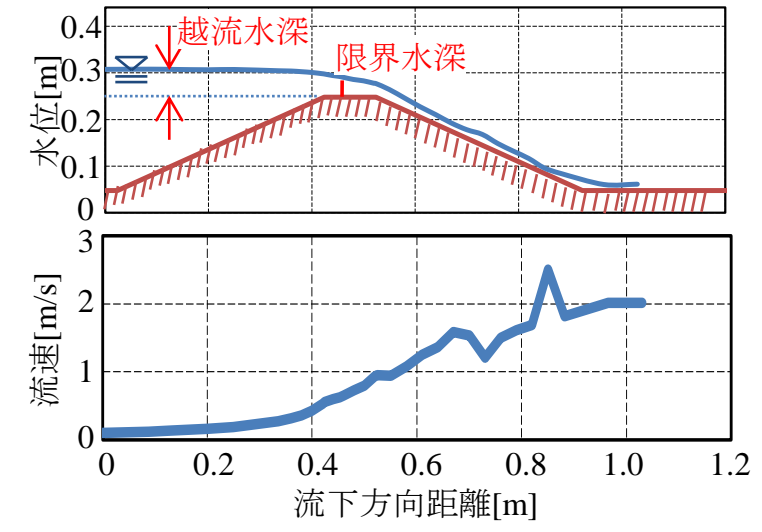

図-6 木製模型を用いた時の水面形及び流速の縱断変化

-5）を用い，厚さ $2 \mathrm{~cm}$ 毎に締め固めて作成した。 また, Case5, 7 において用いるジオグリッドの敷設間隔は高さ $2 \mathrm{~cm}$ とした．基礎地盤にも同じ豊浦砂を用いた。

越流条件としては, 流量 $Q=5.61 \times 10^{-3} \mathrm{~m}^{3} / \mathrm{s}$ と越流水深 $6.0 \mathrm{~cm}$ という 1 ケースを設定した. 模型縮尺 (=1/25) より, 実スケールの越流水深は $1.5 \mathrm{~m}$ と大きいが，越流水深が小 さいと流れが層流化するため，ここではこの条件を選定 した. 吉川 ${ }^{11)}$ に記載された越流水深と越水時間による堤 防決壊の関係図より，実スケールの越流時間は約 50 分と なり，フルードの相似則による時間的縮尺 (=1/5) から模 型実験では約 10 分の越流時間となるので, 越水時間を 10 分とした. このような越流・堤防補強条件下において堤 防越流実験を行い，堤防の変形・侵食状況を側面・上面 からの DVカメラ（HDR-XR550V，SONY製）を用いて堤 体の側面・上面の 2 方向から同時にビデオ撮影し，堤防 の侵食量を定量評価した.

本条件における基本的な流況を把握するために，図-4 と同じサイズの木製模型を用いて，越流実験を行った. その際に得られた水面形の縦断変化を図一に示寸. 図中 には, 単位幅流量からも求められる限界水深 $(=4.3 \mathrm{~cm})$ と 同じく単位幅流量と各地点の水深から得られる平均流速 の縦断変化も合わせて表示している，これを見ると，限 界水深は，天端の前方で生じており，そこから天端のり 肩から裏のり面では水深が $2.9 \mathrm{~cm}$ から $1.4 \mathrm{~cm}$ と減少して いる. また, 水深から得られる流速は, 天端のり肩部で $1 \mathrm{~m} / \mathrm{s}$ となり, 裏のり面では流れが加速し, のり尻部では $2 \mathrm{~m} / \mathrm{s}$ 越える流速を記録している.

\section{4. 結果と考察}

\section{（1）締固め度が堤防侵食に及ぼす影響}

越流時における土堤の而越流侵食性に関する基本特性 を把握するために，締固め度 $D_{c}$ が $85 \%$ の場合（Case2） における堤体形状の時間変化を図-7に示す。ここでは, 越流開始からの時間 $t=10 \mathrm{~s} ， 20 \mathrm{~s} ， 40 \mathrm{~s}$ における堤体形状を 


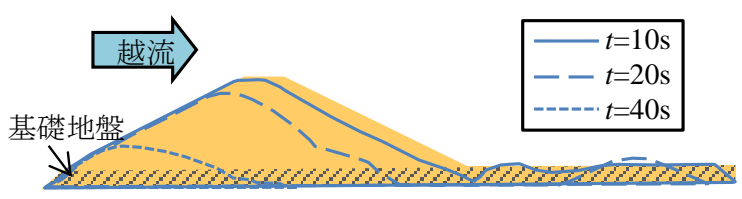

図-7 堤体の侵食状況の時間変化（Case2，無補強， $D=85 \%$ )

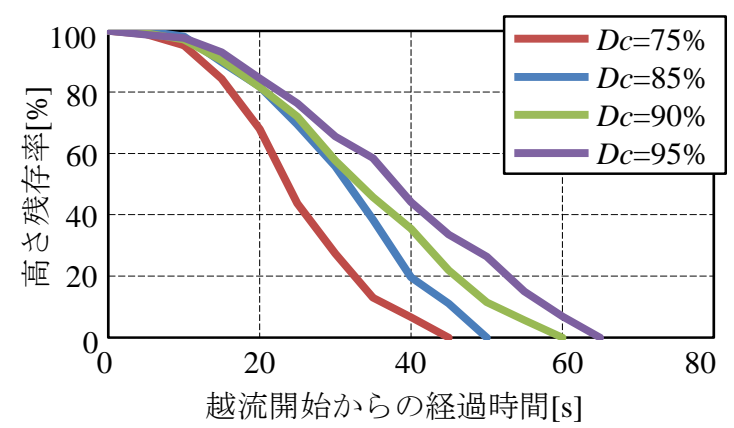

図-8＼cjkstart締固め度 $D_{c}$ による耐越流侵食性の比較

表示している.これを見ると， $t=10 \mathrm{~s}$ の時には天端は残つ ており，表のり面の侵食も見られないが，裏のり面は全 面的に侵食されており，その侵食深は概ね一様である. また，この時点では，裏のり尻における洗堀深は基礎地 盤厚さ全体 $(5 \mathrm{~cm})$ に到達しているが，その範囲はこの段 階では狭い， $t=20 \mathrm{~s}$ の時には，天端全体や裏のり面が全体 的に侵食され，堤体面積は大幅に減少している。また， 裏のり面の傾きは，多少の凹凸は見られるものの，初期 断面と同じ 2 割勾配を維持した形で侵食がほぼ一様に進 行している. さらに，基礎地盤の洗堀が進み，広範囲に わたり侵食されている様子が伺える.さらに, t=40sでは, 堤体の大部分が侵食されるとともに，堤体が残存してい る部分を除いて基礎地盤まで侵食されている，その後， $t=50 \mathrm{~s}$ 頃には, 堤体の全ての部分が流出した (図面省略).

この土堤の越流侵食状況に対寸る締固め度の影響を把 握するために，締固め度 $D_{c}$ を $75 ， 85 ， 90 ， 95 \%$ とした 4 ケースにおける堤体の高さ残存率を図-8 に示寸. 高さ残 存率とは, 側面からビデオ撮影した堤体断面の画像から 時々刻々の高さを求め，それを越流開始時の初期高さで 除したものである。これより，全般には，高さ残存率は 締固め度が小さいほど大きく減少し，特に締固め度 75\% の時にその傾向が顕著となる. 締固め度 $75 \%$ における侵 食状況を観察すると，他のケースと異なり，越流開始前 の表のり面側で水位が上昇している時から表のり面で侵 食が始まり，この時点で流れが非常に緩やかであること を考慮すると, 浸透のみで堤体の変状が現れたものと推 察される．また，締固め度 $95 \%$ における高さ残存率は締 固め度 $85,90 \%$ の結果をやや上回る程度であり, 高さ残 存率が 50\%になる時間は締固め度 85，90，95\%でそれぞ れ 32，33，38s となり，その差は小さい. このように，堤 体の締固め度を大きくすると堤体の侵食状況を抑制でき

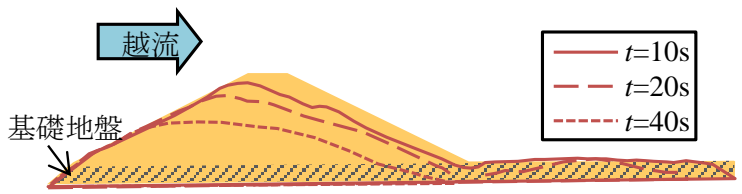

（a）堤体侵食状況（Case5）

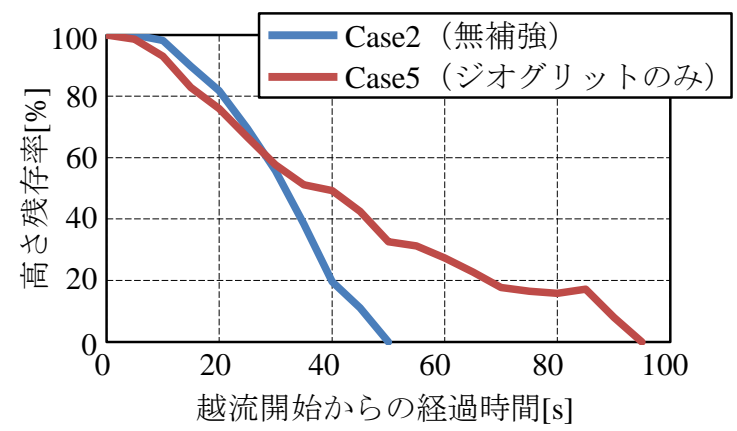

(b) 堤体高さ残存率の時間変化 (Case2 と Case5) 図-9ジオグリッドによる耐越流侵食性向上効果

るものの，締固め度 $85 \%$ 以上では，その差は顕著では無 い. また，締固め度 $85 \%$ 以下の場合 (=75\%) では，間隙 比が非常に大きく浸透能が高いため，浸透の影響のみで も堤防形状が変状し，結果として，堤体の侵食量が大き くなることが示された．なお，ここに示した実験結果は 貧配合（均等係数が小さい）豊浦砂での結果であり，今 後、現場で用いられることが多い一定の細粒分含有率を 含んだ均等係数の高い砂質土での検討が必要である。ま た，締固め度以外にも堤防形状や湿潤度などが而侵食性 に関係しており，今後検討する必要がある。

\section{（2）ジオグリッド補強の効果}

次に，堤防補強対策を施した効果を把握するため，面 状補強材としてジオグリッドを導入した Case5 における 堤体侵食形状及び高さ残存率の時間変化を図-9 亿示す.

同図（b）には，比較のために，同じ締固め度 $85 \%$ で無補 強の結果（Case2）を合わせて表示している．まず，堤体 の侵食形状としては， $t=10 \mathrm{~s}$ の時には，天端の一部や裏の り面において侵食が始まっているものの，裏のり面 の侵食状況としては一様ではなく，無補強の場合（図-7） と比べて裏のり尻側の侵食が明瞭に抑制されている。 こ

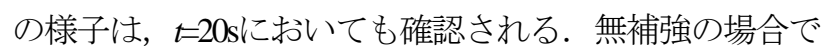
は裹のり面の勾配は初期断面の 2 割勾配をほぼ維持した まま侵食が進行していたが，ジオグリッド補強を行った Case5ではそれよりも緩やかになっていることが分かる. これは, 裏のり面の侵食に伴って露出するジオグリッド が表面を覆うことで侵食速度そのものを抑制しているこ とが第一の理由である.これに加えて, 裏のり面の勾配 が緩やかになるため, 堤体表面に作用する底面摩擦力を 低下させている. ジオグリッドの敷設により，これらの 二重の効果が現れ，而侵食性を向上させている. 

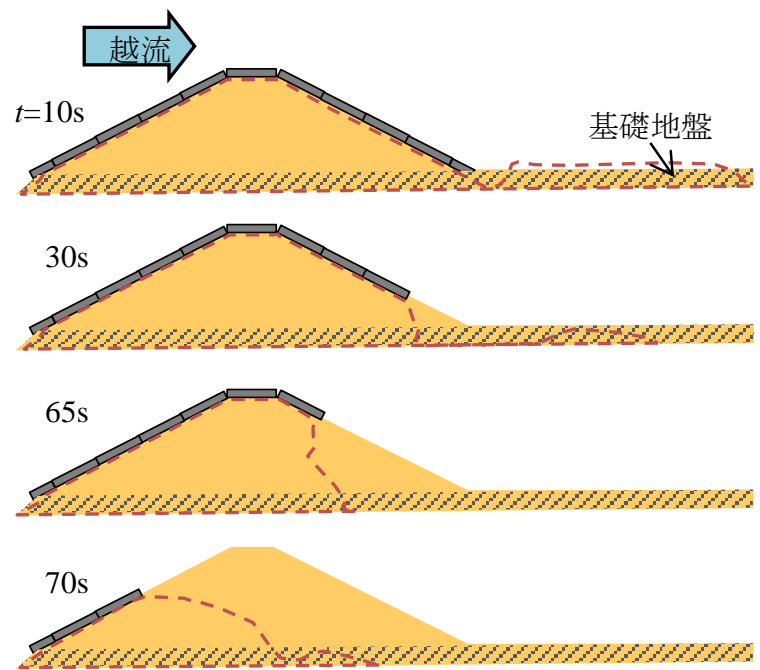

(a) 従来形式 (Case6)
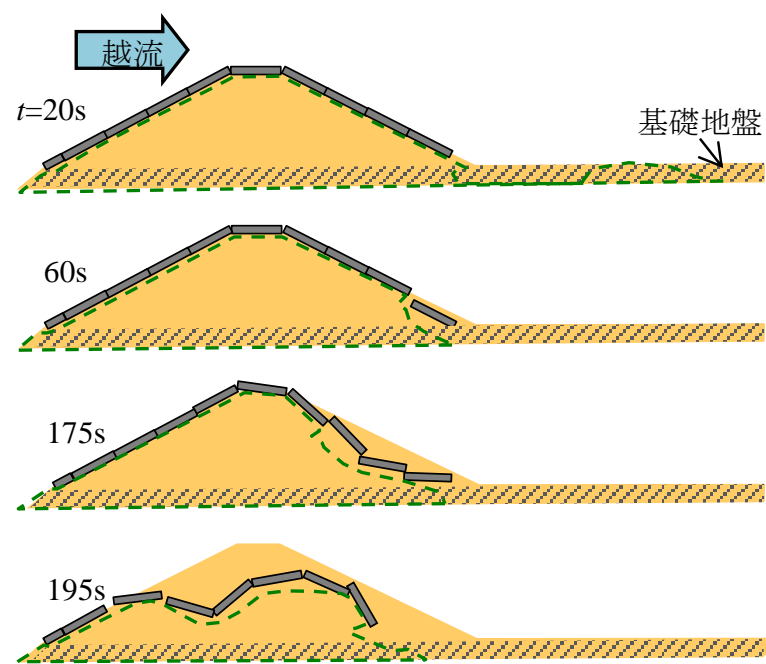

(b) 新形式 (Case7)

図-10 従来形式と新形式の堤体侵食状況の比較(新形式の断面図は図 2（a）参照)

また，同図（b）に示される堤体の高さ残存率はジオグ リッド補強により抑制された。 具体的には，堤防が全て 流失される時間は，無補強では45s，ジオグリッド補強で は90sであり，ジオグリッド補強により2倍に伸びた。この ように，ジオグリッドによる一定の補強効果が現れてい るが,このケースでも90s後には堤体全てが流出しており， より而越流侵食性の高い盛土補強技術が必要亡なる.

\section{(3) 従来形式と新形式堤防の比較}

上記から求められる堤防補強技術として, 従来形式と 新形式堤防が適切から゙うかを調べるために，まず，従来 形式（Case6）及び新形式堤防（Case7）における堤体侵食 状況の時間変化を図-10に示す，図中では，堤体中の盛土 表面部分を点線で示すと共に，パネルの存在状況も実態 に合わせて図示している. なお，新形式堤防では，ジオ グリッドが敷設されているが，その様子は図中では省略 した. また, いずれも, 堤体天端付近が侵食され, 堤体 形状が大きく変状するまでを表示している.

まず，従来形式（Case6）の場合には，越流開始直後の $t=10 \mathrm{~s}$ では裏のり尻部分が局所洗掘され，パネル下側の土 砂が下流側一流送された。 その侵食がある程度進行する と $(t=20 \mathrm{~s})$, 裏のり尻側のパネルから流失し, 再び, 残 されたパネル下部の侵食が進行した. これらを繰り返し, 天端付近まで侵食面が到達すると（t=65s），天端から一 気に崩壊し，堤体の大部分が侵食された（ $t=70 \mathrm{~s} ）$.

一方，新形式堤防（Case7）のケースでは，従来形式 (Case6） と同様に, $t=20$ sでは裏のり尻部の局所洗掘によ り，パネル下部の侵食が進むが，パネルがジオグリッド と結合されているため，パネルは流失せずに，概ねその 位置に留まっていた。 その後, 裏のり尻部での侵食がよ り進行すると（t=60s），そこでのパネルや結合するジオ グリッドの位置は変化するものの, 流失や変形している
様子が分かる. その後, 時間と共に, 裏のり尻から堤体 の土砂が流出し，裏のり面のパネルの変位量が大きくな り，パネルが図中時計周りに回転し流れへの抵抗が増大 すると ( $t=175 \mathrm{~s})$, そのパネル近傍で激しい渦運動が生じ, そこから, より多くの土砂が堤体内から流出し, 結果と してパネルや堤体全体は大きく変形した $(t=195 \mathrm{~s})$. なお, パネル自体の流失は，このケースでは見られておらず, パネルと結合されたジオグリッドの効果が有効であった ことが分かる。

これらの結果を定量的に比較するために，堤体の面 積・高さ残存率の時間変化を図-11に示す。ここでは，従 来形式 (Case6) と新形式 (Case7) に加えて, 無補強 (Case2) の結果を表示している. 面積残存率は, 時々刻々の堤体 面積を初期断面積で除したものである。また，通水時間 10分間の結果である.これより, 従来形式 (Case6) では, 図-10(a)で示したように, 急激に面積・高さ残存率が減少 しており, 90後には, 完全に流失している.このように, 従来形式のように，パネル敷設のみでも堤体形状を維持 する時間を長くできているものの，一端侵食が進行する と急激に破堤に至ることが分かる. 一方, 新形式 (Case7) では, $t=175 \mathrm{~s}$ ま゙堤体の面積・高さ共に初期状態を維持で きており，本実験条件の中では最も長い時間に耐えてい る.ただし，その後は，図-10(b)で示したように，堤体は 大きく変形し, 堤体の面積・高さ共に大きく減少する. しかしながら，新形式堤防は，盛土と共にある程度変形 し, その後は面積・高さ共に概ね一定となり, $t=600$ sでは. 高さ残存率は $32 \%$ を維持していた。このように，新形式 堤防は，完全な破堤を回避できている.

以上のように，新形式堤防は，従来形式や無補強の土 堤の場合と比べて堤体侵食を大幅に抑制し，100\%に近い 面積・高さ残存率を3分程度維持できていた．また，大き 

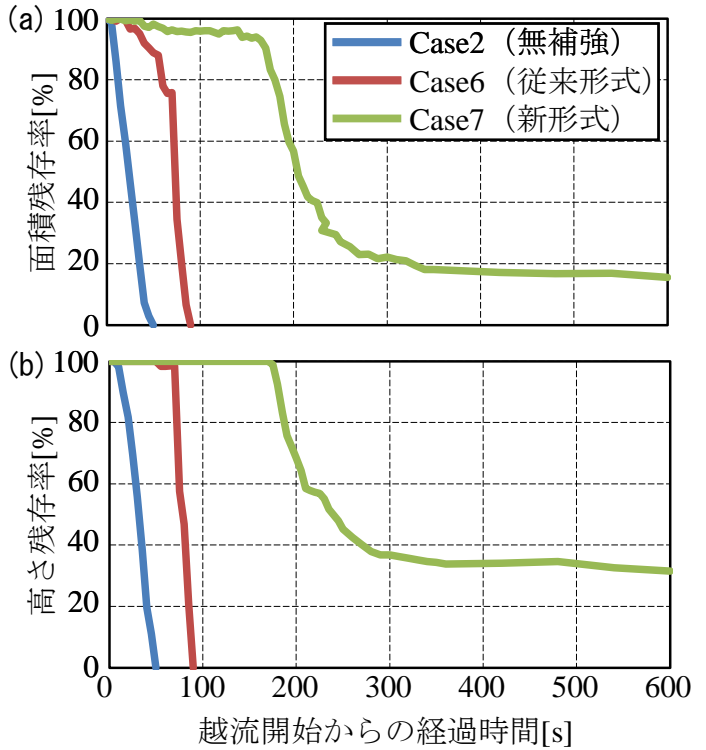

図-11 堤体面積 (a) と高さ (b) 残存率の時間変化（無補強 (Case2) と従来形式 (Case6)， 新形式 (Case7))

な堤体変形が生じた後も，完全に崩壊せず，越流時間が 10分後でも高さを初期断面の $1 / 3$ 残しており，かなり粘り 強い堤防と言え，新形式堤防における而越流侵食性の向 上が明らかとなった．ただし，現状では，新形式堤防で も大きく変形・侵食されており, 裏のり尻付近のパネル の安定化などより精緻な補強対策の検討が必要である. 従来・新形式堤防の場合には，いずれも裏のり尻部から 洗掘されているため, 裏のり尻部の洗掘防止工の設置が 必要不可欠であり, 今後, その実験を行う予定である.

\section{5. 結論}

本研究で得られた主な結論は以下のとおりである.

1）堤体の締固め度を大きくすると，堤体の侵食状況を ある程度抑制できることが示された。また，締固め 度75\%の場合では，間隙比が非常に大きく浸透能が 高いため，浸透の影響のみでも堤防形状が変状し， 堤体の侵食量が大きくなった.

2）堤体にジオグリッドを導入した場合，無補強のもの と比へ，越流侵食時の裏のり面の勾配が緩やかにな り，侵食量を抑制しており，ジオグリッド補強によ り，一定の耐越流侵食性向上効果が確認された.

3）従来形式のようなパネル敷設のみでも，堤体形状を 維持する時間を長くできるものの，一端侵食が進行 すると急激に破堤に至る.

4）新形式堤防では，ジオグリッドとパネルを結合させ ることにより，パネルの流失を防ぎ越流侵食を大幅 に抑制できている．また，盛土変形に合わせて新形 式堤防も変形して完全な破堤を回避でき, 越流時間 が10分後でも高さを初期断面の約 $1 / 3$ に維持できてい
た。これより，新形式堤防による而越流侵食性の向 上が明らかとなった。

本実験にてフルードの相似則に基づくと，力の現地 / 実験の比は縮尺の3乗（=1/15625） となる．パネル自体の 重力は，パネルサイズを縮小させているので相似則を満 たす。一方，新形式堤防で用いるジオグリッドの引張強 度は10〜100kN/mのオーダーのものしか存在しないため, 上記の相似則を満足できていない．本実験で用いたジオ グリッドとしては小さな引張強度のものを採用したが, 現地スケールで比べるとそれでもジオグリッドの強度を 過大に与えていることになる，同様のことは，ジオグリ ッドと被覆工の接着強度についても言える，今後，被覆 工に作用する力を計測し, 必要となるジオグリッドの強 度を求め, 相似則の妥当性を検討寸る必要がある.

\section{参考文献}

1) 玉井信行 : 2011 年 7 月新潟・福島豪雨災害の概要と超過洪 水対策について, 平成 23 年度河川㷋害に関するシンポジウ ム, pp.1-14, 2012.

2) 角哲也, 竹林洋史 : 2011 年台風 12 号に伴う紀伊半島の災害 概要と総合土砂管理への課題, 平成 23 年度河川災害に関す るシンポジウム, pp.15-24, 2012.

3）(社)日本河川協会編 : 改訂新版建設省河川砂防技術基準 (案)同解説 設計編[I], pp.3-30, 1997.

4) 土木学会 : 水理公式集 [平成 11年版], 丸善, pp.194205, 1999.

5) Tatsuoka, F., M, Tateyama, T. Uchimura and J. Koseki: Geosynthetic-reinforced soil retaining walls as important permanent structures, 1996-1997 Mercer Lecture, Geosynthetic Intermational, Vol.4, No.2,pp.81-136, 1997.

6) Tatsuoka, F., J. Koseki, M. Tateyama, Y. Munaf and N. Horii: Seismic stability against high seismic loads of geosynthetic-reinforced soil retaining structures, Keynote Lecture, Proc. 6th Int. Conf. on Geosynthetics, Atlanta, Vol.1,pp.103-142, 1998.

7) Tatsuoka, F., D. Hirakawa, M. Nojiri, H. Aizawa, H. Nishikiori, R. Soma, M. Tateyama and K. Watanabe: A new type integral bridge comprising geosynthetic-reinforced soil walls, Geosynthtetics Intemational, IS Kyushu 2007 Special Issue, Vol.16, No.4,pp.301-326, 2009.

8) 柳沢舞美, 二瓶泰雄, 山口晋平, 川邊翔平, 龍岡文夫 : 海 岸砂丘と補強盛土技術を組み合わせた新形式防潮堤の提 案, 土木学会論文集 B2 (海岸工学), Vol.59, pp.I_886-I_890, 2012.

9) 山口晋平, 柳沢舞美, 川邊翔平, 龍岡文夫, 二瓶泰雄 : 小 型模型実験による防潮堤の 越流津波に対寸る安定性の評 価, ジオシンセティックス論文集, Vol.27, 2012 (印刷中) .

10) 箱石憲昭, 坂野章: 河川堤防の耐震食機能向上技術の開発, 平成 22 年度重点プロジェクト研究報告書, pp1-12, 2010.

11）吉川勝秀（編著）：河川堤防学 新しい河川工学，技報堂 出版, pp.1-278, 2008.

(2012. 9.30 受付) 